\title{
A Rare Case of Pediatric Self-inflicted Meningoencephalocele
}

\author{
${ }^{1}$ MK Rajasekar, ${ }^{2}$ Malarvizhi R Sankar
}

\begin{abstract}
Cerebrospinal fluid (CSF) rhinorrhea is common in traumatic penetrating nasal injuries. In the pediatric age group, we often encounter self-inflicted foreign body injuries of blunt type, which rarely leads to any complications. We came across a case of CSF rhinorrhea due to self-inflicted penetrating nasal injury, after 7 years of initial injury. In this case, the sharp end of a screw nail had injured the fovea ethmoidalis and caused a meningoencephalocele on removal, which had been asymptomatic until 4 years ago, when the patient came with CSF rhinorrhea. Miraculously, there were no complications in the period before presentation and after surgical correction.
\end{abstract}

Keywords: Cerebrospinal fluid rhinorrhea, Endonasal approach, Pediatric trauma, Screw nail trauma

How to cite this article: Rajasekar MK, Sankar MR. A Rare Case of Pediatric Self-inflicted Meningoencephalocele. Clin Rhinol An Int J 2016;9(3):143-145.

\section{Source of support: Nil}

Conflict of interest: None

\section{INTRODUCTION}

Meningoencephalocele (Latin - cranium bifidum) $)^{1,2}$ is the protrusion of meninges and brain tissue with cerebrospinal fluid (CSF) rhinorrhea through a skull base defect. Congenital meningoencephaloceles are due to neural tube defects. There are two main types of meningoencephalocele, which are named according to the location of the sac. The frontoethmoidal type is located at the frontal and ethmoidal bones, while the occipital type is located at the occipital bone. The condition is typically congenital (present at birth), but has been reported to develop by chance in older individuals in rare cases. The underlying cause of the condition is uncertain, but environmental factors are thought to play a role. Treatment depends on the size, location, and severity of the defect, but mainly includes magnetic resonance imaging to determine the severity of the defect, followed by surgery to repair it. ${ }^{3}$

\footnotetext{
${ }^{1}$ Professor, ${ }^{2}$ Postgraduate Student

1,2Department of ENT, Madras Medical College, Chennai, Tamil Nadu, India

Corresponding Author: Malarvizhi R Sankar, Postgraduate Student, Department of ENT, Madras Medical College Chennai, Tamil Nadu, India, Phone: +914422390909, e-mail: mavi_20042003@yahoo.com
}

Here we report on a patient with posttraumatic meningoencephalocele who presented 7 years after trauma with CSF rhinorrhea due to condition being rare in pediatric age group, wherein it is generally congenital mode of presentation.

\section{CASE REPORT}

An 11-year-old male child came to the outpatient department with complaints of watery nasal discharge from the left side of nose for the last 3 years, with increase in discharge in the mornings. The mother gave a history of trauma to the child's nose 7 years earlier: The child had inserted a screw nail into his left nostril when he was 3 years old; there was some bleeding when it was removed. There were no major complaints until 3 years ago when he started having nasal discharge on and off. It progressed to increased nasal discharge with noticeable nasal drip (reservoir sign) in the early mornings when the child woke up from sleep.

The child was admitted and workup proceeded. The nasal fluid was confirmed as CSF with biochemical analysis. Computerized tomogram of paranasal sinuses with anterior skull was taken, which showed a defect in the left fovea ethmoidalis. Computed tomography cisternography was done to confirm the leak site (Figs 1 to 3).

Under aseptic conditions and under general anesthesia diagnostic nasal endoscopy revealed a nonviable

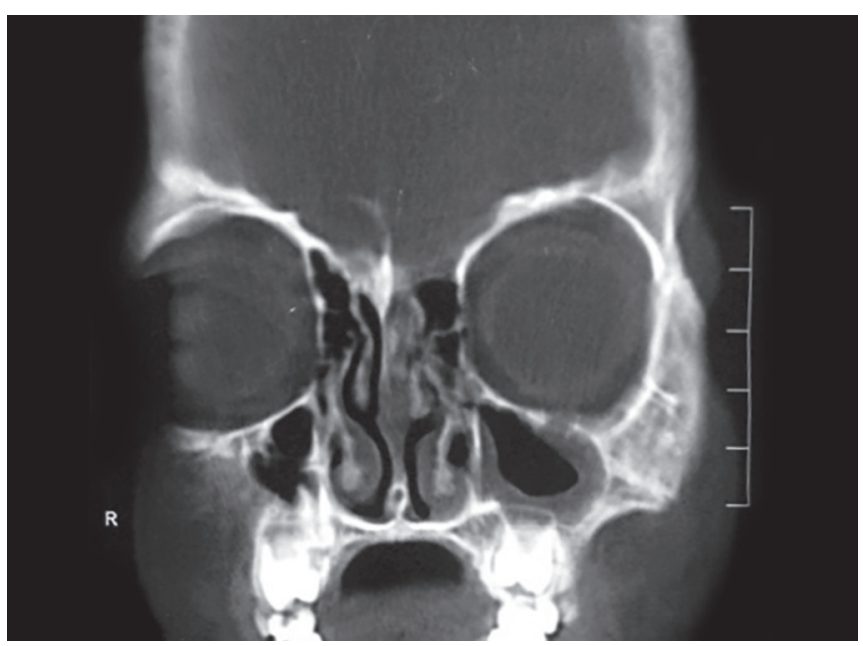

Fig. 1: Computed tomography paranasal sinus showing leftsided fovea ethmoidal defect with meningoencephalocele 


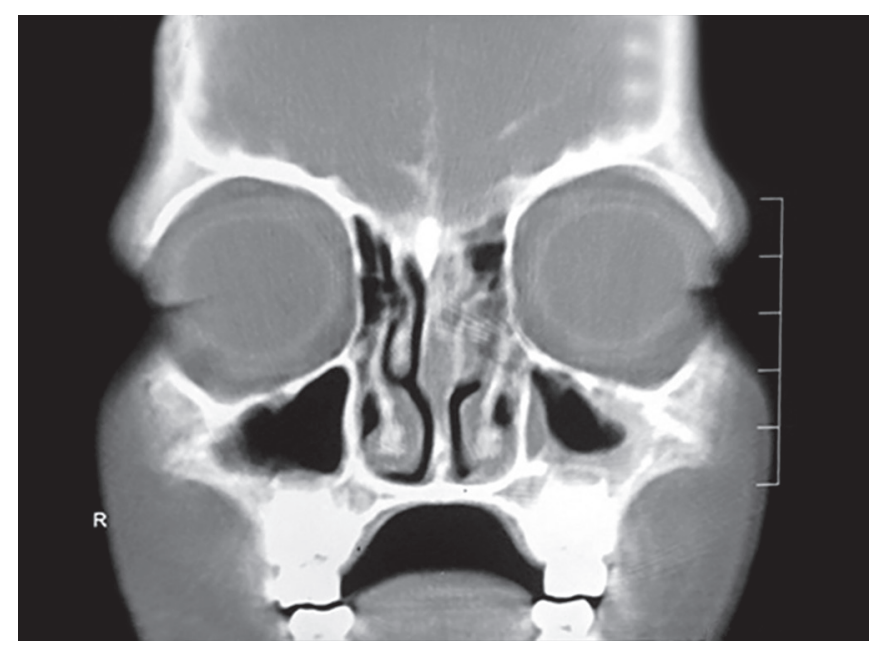

Fig. 2: Computed tomography cisternography showing fovea ethmoidal leak on the left

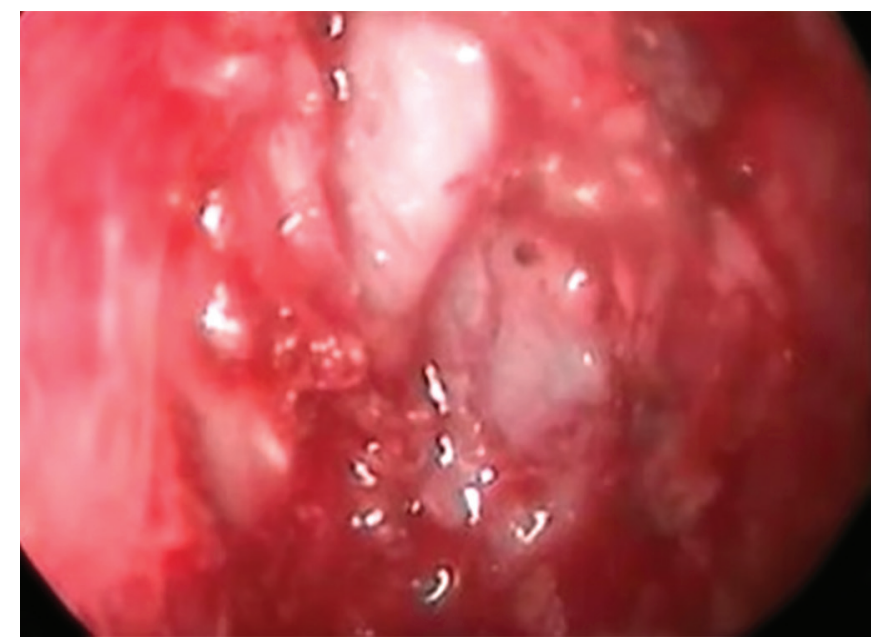

Fig. 4: Preoperative diagnostic nasal endoscopic view of meningoencephalocele medial to middle turbinate on the left nasal cavity

meningoencephalocele medial to left middle turbinate with CSF leak from its site of defect.

Transnasal endoscopic leak closure of defect ${ }^{4}$ was done with the help of Hopkins Rigid Rod II endoscope. The nonviable brain tissue was cauterized with radiofrequency bipolar cautery and defect closure done using septal cartilage, fascia lata, and muscle and fat tissue. In addition, tissue glue was used in a sandwich manner to reinforce the layered closure (Fig. 4).

Follow-up diagnostic nasal endoscopy was done at 3 weeks and at 4 months in the postoperative period. The graft had taken up well and there was no active leak (Fig. 5).

\section{DISCUSSION}

Until the 1940s, Dandy's bifrontal craniotomy ${ }^{4}$ was the procedure of choice for CSF leak repairs, the main disadvantage of it being its permanent anosmia and

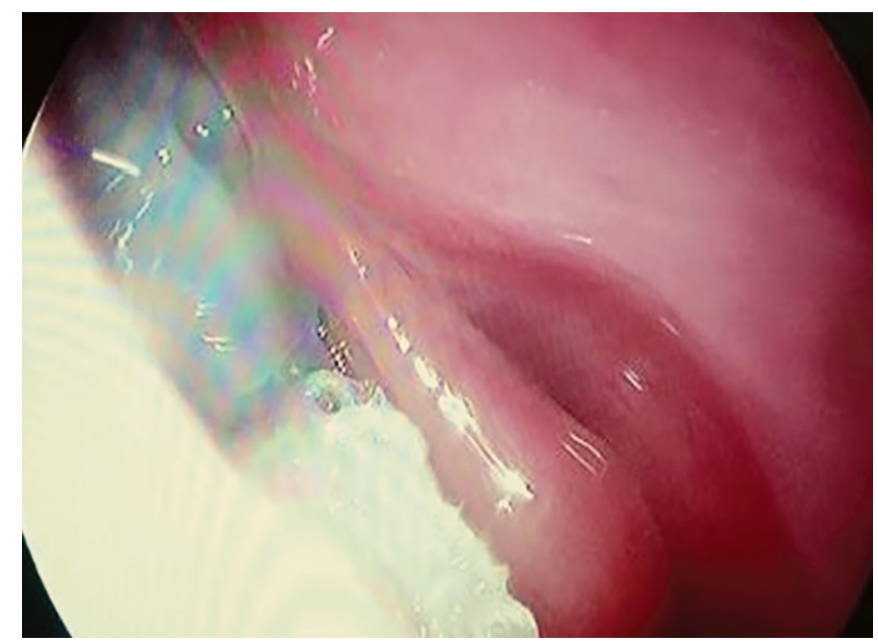

Fig. 3: Preoperative diagnostic nasal endoscopic view of meningoencephalocele medial to middle turbinate on the left nasal cavity

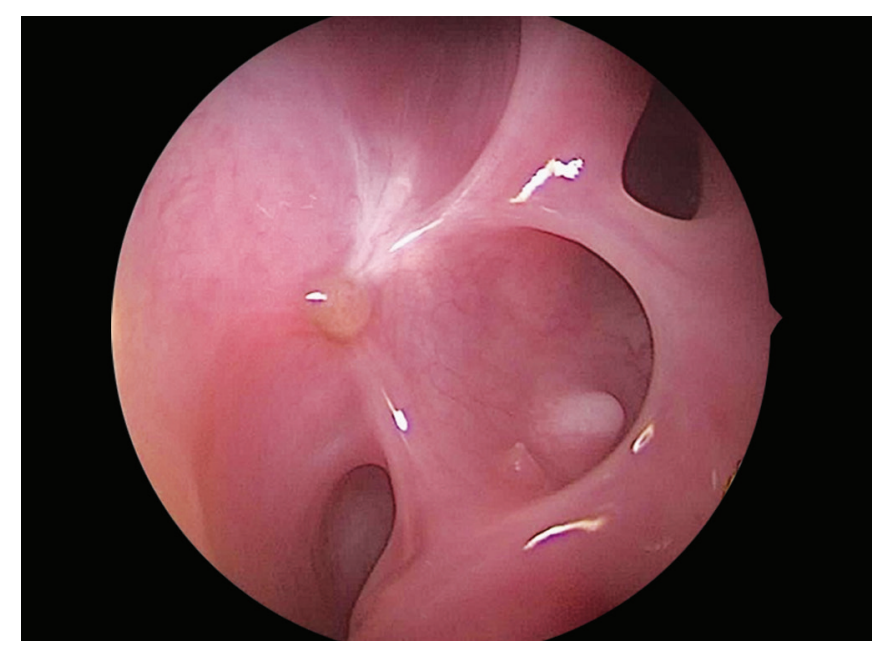

Fig. 5: Preoperative diagnostic nasal endoscopic view of meningoencephalocele medial to middle turbinate on the left nasal cavity

morbidity. Approaches described by Dohlman and Chandler through ethmoidal sinus externally posed the middle turbinate resection as a disadvantage. With the advent of straight and angle scopes and fiber optic camera cable system, transnasal closure was possible, which eliminated the disadvantages of anosmia and external incision.

The etiology of CSF leaks ${ }^{1}$ is shown in Table 1.

Cerebrospinal fluid is produced by choroidal plexus in the lateral, $3 \mathrm{rd}$, and 4 th ventricles of brain. The intracranial CSF volume has been estimated at $123 \mathrm{~mL}$. It is secreted at the rate of 0.35 to $0.4 \mathrm{~mL} /$ minute; $50 \%$ is replaced in 5 to 6 hours. Historically, the most common cause of CSF leak was trauma. Spontaneous leaks and

Table 1: The etiology of CSF leaks

\begin{tabular}{ll}
\hline latrogenic & $17 \%$ \\
Trauma & $3 \%$ \\
Spontaneous & $7 \%$ \\
\hline
\end{tabular}


Table 2: Causes

\begin{tabular}{|c|c|c|c|c|c|}
\hline Congenital & Idiopathic & Surgical trauma & $\begin{array}{l}\text { Nonsurgical } \\
\text { trauma }\end{array}$ & Inflammatory & Neoplasm \\
\hline $\begin{array}{l}\text { Meningocele (or) } \\
\text { meningoencephalocele }\end{array}$ & \multirow[t]{3}{*}{$\begin{array}{l}\text { Unknown } \\
\text { cause }\end{array}$} & \multirow{3}{*}{$\begin{array}{l}\text { Intranasal injury } \\
\text { Endoscopic sinus } \\
\text { surgery } \\
\text { Transcranial approaches } \\
\text { to middle and posterior } \\
\text { cranial fossa }\end{array}$} & \multirow{2}{*}{$\begin{array}{l}\text { Skull base } \\
\text { fractures } \\
\text { Open or } \\
\text { penetrating } \\
\text { injuries }\end{array}$} & $\begin{array}{l}\text { Erosive lesions - mucoceles, } \\
\text { polypoid disease, cystic fibrosis, } \\
\text { fungal sinusitis, osteomyelitis }\end{array}$ & $\begin{array}{l}\text { Neoplasms } \\
\text { invading skull } \\
\text { base }\end{array}$ \\
\hline defects & & & & Postinfective hydrocephalus & Intracranial \\
\hline $\begin{array}{l}\text { Congenital } \\
\text { hydrocephalus }\end{array}$ & & & $\begin{array}{l}\text { Posttraumatic } \\
\text { hydrocephalus }\end{array}$ & & $\begin{array}{l}\text { causing } \\
\text { hydrocephalus }\end{array}$ \\
\hline
\end{tabular}

congenital causes are rare. The risk of developing one or more episodes has been quoted between 5.6 and $60 \%$. Time of onset of CSF rhinorrhea and meningitis can vary from 2 to 2,285 days (Table 2). ${ }^{4}$

Encephaloceles are generally congenital. ${ }^{2}$ Incidence (1 in 12,500) in live births does not reflect true statistics as may occur in stillborns. There has been no reported familial association or sex predilection; $40 \%$ have other associated anomalies. Based on their presentation, encephaloceles have been divided into occipital, sincipital, and basal types. Embryological encephalocele is believed to be due to faulty closure of foramen cecum in the 3rd week of fetal development, leading to potential extrana$\mathrm{sal} /$ nasofrontal path of herniation of brain tissue covered with meninges. Sincipital encephaloceles (nasal dorsum, orbits, forehead with external mass), basal encephaloceles (nasal cavity, nasopharynx, or posterior aspect of orbits). Encephaloceles may be subdivided with respect to their contents as meningoceles, encephalomeningoceles, and encephalomeningocystoceles. ${ }^{2}$

A viable meningoencephaloceles is smooth, gray pink, glistening, and pulsating in nature. When herniated brain tissue is necrotic, it is yellow-white and nonpulsatile. The nonviable tissue is resected without shearing force, and the defect is closed by graft with its epithelial layer facing the cranial vault. ${ }^{4}$

Cerebrospinal fluid leak management lies in the identification of dural tear. In cases of blood with CSF, the fluid appears dark due to CSF not being reflective as the surrounding blood. ${ }^{5}$ Cribriform leaks with or without meningoceles pose the challenge of accessibility due to narrow olfactory groove and immobility of middle turbinate. The mucosa surrounding the defect is elevated for at least $5 \mathrm{~mm}$ in all directions to create a circumferential raw surface for graft and provide a flat recipient surface by removing redundant ethmoidal mucosa. Small lesions (of meningoceles and meningoencephaloceles) are cauterized at base and excised. Larger lesions are managed by resetting mucosa of the surface and reducing with debrider or radiofrequency cautery and supported with bone or cartilage graft. ${ }^{5,6}$

\section{CONCLUSION}

Screw nail and such penetrating foreign bodies penetrating the nose should always be carefully handled to prevent inadvertent morbidity in terms of complications. Smooth and gentle extraction followed by examination of site of injury is the need of the hour.

\section{REFERENCES}

1. Kennedy DW. Textbook of the Sinuses - diagnosis and management.

2. Bluestone CD, Simons JP, Healy GB. Bluestone and Stools's pediatric otolaryngology. 5th ed. USA: People's Medical Publishing House.

3. Yadav JS1, Mohindra S, Francis AA. CSF rhinorrhea feasibility of conservative management in children. Int J Pediatr Otorhinolaryngol 2011 Feb;75(2):186-189.

4. Gleeson MJ, Clarke RC, editors. Scott Brown's otorhinolaryngology and head and neck surgery. 7th ed. New York: CRC Press; 2008.

5. Hegazy HM, Carrau RL, Snyderman CH, Kassam A, Zweig J. Transnasal endoscopic repair of cerebrospinal fluid rhinorrhea: a meta-analysis. Laryngoscope 2000 Jul;110(7):1166-1172.

6. Wen W, Xu G, Zhang X, Shi J, Xie M, Li Y, Chen H, Wang H. Surgical management of cerebrospinal fluid rhinorrhea. Zhonghua Er Bi Yan Hou Ke Za Zhi 2002 Oct;37(5):366-369. 